\title{
Gaps in protest activities between natives and individuals of migrant origin in Europe*
}

\author{
Pilati Katia ${ }^{1}$
}

\begin{abstract}
This article explores gaps in protest engagement between natives and individuals of migrant origin in European cities. It examines migrant-native gaps and second generation-native gaps by associating them with different sources of inequalities: differential individual SES resources, differential attitudes, and differential characteristics related to migration; differential effects of such factors for natives and for individuals of migrant origin; and differential contexts offering varying opportunities of participation. The study uses cross-national micro-data from a population survey of immigrant-origin individuals and natives in 9 European cities undertaken in 2004-2008. The findings show that observed inequalities in protest participation involving migrants and second generations are largely based on different levels of education attained and of political interest. Some migration-related characteristics, like holding the citizenship of the host country and experienced discrimination, affect protest gaps as well. In addition, results support the claimed importance of the context where individuals of migrant origin settle, in particular, of the characteristics of the citizenship regime. Finally, our findings support a segmented assimilation hypothesis whereby different socio-economic modes of incorporation of ethnic groups in the host cities affect different trajectories of political incorporation.
\end{abstract}

\section{Keywords}

Inequalities, immigrants, second generations, Europe, political, participation, protests

Date received: 16 October 2015; revised: 23 July 2016 and 12 January 2017 accepted: 29 March 2017

\footnotetext{
${ }^{1}$ Department of Sociology and Social Research, University of Trento, Italy 


\section{Introduction}

Differential rates of political participation for any subgroup of the population deserve thoughtful analysis, but differences between natives and individuals of migrant origin in Europe are particularly noteworthy, given the constantly increasing growth in the inflows of the foreign population to most European countries. Indeed, the lack of political participation by individuals of migrant origin may lower governments' legitimacies, the acceptance of a democratic form of government, and the sense of collective responsibility and civic duty. It also threatens the equal protection and political representation of a group's interests (Desposato and Norrander, 2008). This article examines the political participation of individuals of migrant origin, both foreign-born individuals and second generations, in European cities. So far, extant literature shows low participation in various forms of political activities by individuals of migrant origin in Europe (Maxwell, 2010; de Rooij, 2012; Voicu and Comşa, 2014; Pilati, 2016). According to this evidence, ethnic diversity due to immigration has a negative impact on levels of civic and political participation (cf. Putnam, 2007). However, studies on the effect of ethnic diversity on dimensions such as trust show that its impact is not significant if we take into account individual socio-economic resources, and characteristics of neighborhood areas such as segregation indexes (Gesthuizen et al 2009; Hooghe et al 2009; Sturgis et al 2011; Gijsberts et al 2012).

Furthermore, most analyses on migrants' political participation focus on an undifferentiated aggregate of individuals of migrant origin. The specific literature on the political participation by second generations is rather scant, especially in Europe, and shows that political participatory gaps between second generations and natives tend to be less marked than gaps between migrants and natives (in the US cf. Ramakrishnan and Espenshade, 2001; Terriquez and Kwon, 2015; in Europe cf. Heath et al 2013; Sanders et al 2014). Heath et al. (2013: page 186) find that the 1.5 and 2nd generation have participation profiles that are very similar to those of their white British peers. ${ }^{1}$ Nevertheless, there are negative effects of being a second generation among certain ethnic groups in Great Britain (Sanders et al 2014: page 135). Along similar lines, in the US, Ramakrishnan and Espenshade's (2001: page 894) found support for the segmented assimilation hypothesis (Portes and Zhou, 1993; Zhou, 1997; Samson, 2014), whereby different processes of political socialization, and modes of incorporation of migrant communities produce different segmented trajectories and generational patterns of participation.

In this framework, there are several specific questions which remain untested: Do gaps with natives disappear all other conditions being equal, particularly, when access to socio-economic resources is taken into account? Do migrants and their descendants have an equally difficult access to political participation in European cities as natives? And how do gaps in political participation change across European cities?

To approach these questions we focus on protest activities, the most costly, and even less legitimated forms of actions, especially for disenfranchised populations such as migrants. While the investigation of protests is far from exhaustive, protesting is still one modality for migrants to get politically incorporated in the host countries, by promoting critical political skills (Rosenstone and Hansen, 2003). 
Our empirical analysis uses data originating from a population survey at the individual level carried out in 2004-2008 in 9 European cities: Barcelona, Budapest, Geneva, London, Lyon, Madrid, Milan, Stockholm, Zurich (Morales et al 2014). For each city the data consists of comparable random samples of individuals of migrant origin ( $\mathrm{N}$ migrants or foreign-born individuals $=5,568 ; \mathrm{N}$ second and third generations $=1,039)$, and a control group of natives $(\mathrm{N}=3,072){ }^{2}$ This dataset overcomes prior survey limitations on the lack of specific information on the proficiency in the host country language, or the experienced individual discrimination (cf. Maxwell, 2010; Dinesen and Hooghe, 2010; Aleksynska, 2011; de Rooij, 2012; Voicu and Comșa, 2014; Just and Anderson, 2014). In addition, it enables us to distinguish migrants from second generations and to widen existing evidence on which European cities provide more equal opportunities of political participation for migrants and their descendants (Penninx et al 2004: 5).

\section{Explaining protest gaps involving individuals of migrant origin}

We rely on three bodies of literature to discuss sources of protest inequalities and advance specific hypotheses on factors affecting protest gaps involving individuals of migrant origin: studies on political behavior given that protests are one type of political action; studies focusing on collective actions, namely social movements scholars; and studies on political integration of individuals of migrant origin in the host countries.

\section{Differential access to socio-economic resources}

There is sound tradition in political behavior studies of stressing that socio-economic characteristics are the primary determinants of any participatory gap, including gaps affecting migrants and minorities (Verba and Nie, 1972; Brady et al. 1995; Tam Cho, 1999; de Rooji, 2012; Heath et al 2013). Likewise, social movement scholars have long argued that resources individuals and groups are endowed with are primary determinants for protesting (cf McCarthy and Zald, 1977; Melucci, 1996). However, most migrants experience a differential access to various resources compared to the native population in Europe (Messina, 2007). Migrants' employment opportunities are limited to the secondary labour market, as they are mostly occupied in much of the low skilled service work. Furthermore, most second generations have substantially lower access to educational opportunities than their native counterparts (Heath et al 2008; Crul et al 2012). Therefore, we expect that a differential access to socio-economic resources will increase protest gaps involving migrants and their descendants (Hypothesis 1).

\section{Differential migration-related characteristics}

As argued by Tam Cho (1999: page 1147) socio-economic status (SES) variables serve only as partial explanations for the minority population. Characteristics associated with the process of migration also affect migrants' political engagement (Uhlaner et al. 1989; Morales and Pilati, 2011). The degree of assimilation of migrants and their descendants in the host country measured through the years lived in the host country or by holding the citizenship of the host countries is likely to have a positive and significant effect on political engagement (Bloemraad, 2006). In particular, De Rooji (2012: page 465) finds that the length of stay significantly contributes to the explanation for differing patterns of political participation between migrants and the majority. Accordingly, the theory of exposure holds that the more exposure to the host country, the more migrants adapt (Wong et al 2005; Zhou, 1997; 
White et al 2008). Political engagement also depends on the ability to speak the host country language (Ramakrishnan and Espenshade, 2001; Morales and Pilati, 2011). People who lack proficiency in the host country language are inevitably going to be restricted in their access to information about the host country politics (Heath et al 2013: page 41), although, compared to their parents, second generations are reasonably more fluent in the majority language (Diehl and Schnell, 2006). Because of a lower recognition of Islam in Europe (Bleich, 2009), being Muslim may also lower participatory opportunities. In turn, the level of discrimination experienced by individuals of migrant origin may trigger a reactive form of mobilization (Rim, 2009). Although several of these aforementioned characteristics affect natives as well, they mainly concern individuals of migrant origin. Following this literature, we expect protest gaps to be high and significant if assimilation among individuals of migrant origin through citizenship and language of the host country as well as length of stay, are limited. Furthermore, high levels of Muslim migrants are expected to widen gaps, while high levels of experienced discrimination among individuals of migrant origin are likely to reduce gaps (Hypothesis 2).

\section{Differential levels of social and political attitudes}

Social and political attitudes often act as mediating factors between resources and participation (Leal, 2002; Maxwell, 2010; Gijsberts et al 2012). Having access to resources increases the chances to trust people. In turn, high levels of social trust and of political interest are likely to increase chances to engage in the political sphere. With regard to protest, networks among activists facilitate the development of shared solidarities and trust relationships which are associated with protest engagement (Melucci, 1996). However, past studies have shown that levels of social trust and political interest differ among natives and individuals of migrant origin, with migrants scoring lower than natives on such attitudes (Maxwell, 2010; Morales, 2011). Levels of social trust declared by second generations are, in turn, closer to those of natives as second-generations "have been raised in the same society and are likely to share perspectives toward that society's political institutions" (Maxwell, 2010: page 26; Dinisen and Hooghe, 2010).

Following these studies, any differential level of trust and political interest between natives and individuals of migrant origin will be significantly associated with wide protest gaps (Hypothesis 3).

\section{Differential effects}

Hypotheses 1 to 3 advance that gaps are likely to be associated with a differential access to resources, a differential level of migration-related characteristics or a differential level of social and political attitudes. In addition to this, some of these factors may also have a differential effect for natives and for individuals of migrant origin. Tam Cho (1999: page 1152) finds that the effect of education may change depending on whether individuals were educated in another country, and therefore had a different socialization process. Individuals of migrant origin may also have social networks that provide unique political information (Tam Cho, 1999).

Following these studies, we expect the impact of SES resources and of social and political attitudes to be stronger for natives than for individuals of migrant origin, consequently further increasing the gap (Hypothesis 4).

\section{Differential contexts}

Next to the role of a differential access (hypotheses 1 to 3), and a differential effect 
(hypothesis 4), the literature has also drawn attention on the impact of contextual constraints in affecting protest gaps. In particular, some studies in the literature on social movements have shown that the characteristics of the citizenship regimes of the host countries affect migrants' protests (Koopmans et al 2005; Cinalli and Giugni, 2011). Where citizenship regimes are closed, and jus sanguinis and ties with natives prevail over other criteria of citizenship acquisition, like it occurs in Switzerland and Italy, levels of engagement in protests are lower than in more open citizenship regimes like in Great Britain or France. Closed political contexts can both limit access to various types of resources and produce feelings of psychological alienation, widening the sense of political inefficacy, and lowering in-group solidarities (Crul et al 2012).

Therefore, in closed citizenship regimes we expect migrants to be less likely to protest, and gaps with natives to be wider than in open citizenship regimes (Hypothesis 5). ${ }^{3}$

\section{Methods}

The sample

To test the suggested hypotheses, we make use of an individual survey conducted in each of the nine cities studied on a sample of individuals of migrant origin and a sample of natives as the control groups (Morales et al 2014). The survey research design is a three-stage sampling selecting the European cities, the ethnic groups within the selected cities, and then the individuals within each ethnic group.

Concerning the sample of individuals of migrant origin, due to various reasons like the fact that research teams were dealing with difficult populations to sample (Heckathorn, 1997), and due to resource limitations, in most cities it was possible to sample three groups. The lack of more ethnic groups is a limitation of this study given that cultures of participation from different migrants' origin countries are significant in determining migrant civic participation in the host country (Voicu, 2014). ${ }^{4}$ However, this survey still has the advantage of specifically tackling individuals of migrant origin in a wide number of cities. The selected ethnic groups constitute between 10 and 30 percent of the total local population (Kovats et al 2016). The groups were selected based on some criteria. Indeed, each city includes at least one group of long-standing immigration, one of more recent arrival as well as one of Muslim background. Specifically, the survey focuses on the following ethnic groups: in Budapest, Chinese, ethnic Hungarian migrants, and a mixed group of migrants originating from Muslim countries; in Barcelona and Madrid, Ecuadorians, other Latin American Andean and Moroccans; in Geneva, Italians and Kosovars; in Zurich, Turks, Kosovars and Italians; in Milan, Filipinos, Egyptians and Ecuadorians; in Lyon, Algerians, Moroccans and Tunisians; in London, Bangladeshi, Indians and Caribbeans; and in Stockholm, Chileans and Turks (Morales et al 2014). ${ }^{5}$ These groups show several varying characteristics such as the wave of migration to the host countries (post-war immigration characterized the Swiss cities, London and Lyon, and recent flows characterized, in contrast, the Spanish cities, Budapest and Milan).

For each ethnic group, the sample of individuals of migrant origin (at least 250 individuals for each group) was selected based on a probability sampling method, and is representative of foreign-born migrants and their descendants. The random selection methods varied across the cities depending on the availability of suitable sampling frames, the availability of resources, and the previous experience of polling institutes in managing surveys addressed to the migrant populations. In some cities 
extracting samples of individuals of migrant origin from the population registers was feasible (e.g. in Budapest, in the Spanish cities and in Stockholm). In other cities, the lack of a reliable sampling frame required resorting to other sampling strategies, e.g. focused enumeration in London, random dialing in Lyon and in the Swiss cities, and geographical sampling in Milan (see Palacios and Morales, 2013).

Although the sampling methods differed, the questionnaires used were the same for all cities at least as far as core questions were concerned, including those used for the analysis employed in this study. In all cities the questionnaire was submitted to respondents either in their mother tongue or in the language of the host country, depending on the respondents' choice. Overall, we expect the results to be comparable to the best possible extent resulting from sampling difficult populations such as individuals of migrant origin.

Alongside the sample of individuals of migrant origin, data were also collected on a group of around 250 individuals of national origin in each city, the natives. The native sample of this survey shows some discrepancies with other available surveys. In particular, natives' rates of protest participation in our survey are underestimated for some cities (cf. European Values Study 2008 (EVS, 2016)). For some cities, this may be due to different sampling techniques used to select natives and to select individuals of migrant origin. In Milan, for instance, CATI was used to sample natives while geographical sampling was used to sample individuals of migrant origin. This choice was related to the fact that natives in the survey were control groups in the cities. Given that CATI leads to some selection bias in the population sampled (retired people have, for instance, higher probabilities to be selected), results on natives' rates of participation may be partly biased. In this framework, results accounting for higher rates of protest engagement by migrants than by natives need to be interpreted with some caution.

All of the individuals selected, natives and individuals of migrant origin, had to have been present in the cities surveyed for at least 6 months prior to the interview, and to be at least 15 years of age. The whole random sample includes 9,679 individuals in total, specifically, 5,568 migrants distributed in the 9 cities, 1,039 second and third generations distributed in the 5 cites of most long standing immigration (Geneva, London, Lyon, Stockholm and Zurich), and 3,072 natives distributed in the 9 cities.

\section{Dependent variable}

We measure protest engagement by considering individuals who have taken part in a public demonstration during the last 12 months (see the separate online methodological appendix A for full details of the coding of the variables). To examine protest gaps we adopt a relative notion of political participation taking levels of political behaviours from the majority of the population as the comparative standpoint (Morales, 2011: page 29-30). Following previous works (Desposato and Norrander, 2008: page 143; Maxwell, 2010; Dinesen and Hooghe, 2010), in each city we examine the following protest gaps:

1. Migrant-Native Gap= Migrant Participation Rate - Native Participation Rate

2. Second and third generation-Native Gap = Second and third generation Participation Rate - Native Peers Participation Rate ${ }^{6}$

Migrant-native gaps are examined in all 9 European cities using the pooled sample of natives and migrants. Second generation-native gaps are only analyzed in those 
cities of long standing migration with a substantial presence of second generations (at least 5 percent of the overall sample of individuals of migrant origin), namely, Geneva, London, Lyon, Stockholm and Zurich.

Table 1 shows the mean protest rates for natives, for migrants, and for second generations, as well as the protest gaps for each city examined in this study. Several patterns are immediately apparent. With the exclusion of Budapest and Stockholm, natives' average participatory rates are higher than those of migrants, and second generations in all cities. ${ }^{7}$ However, gaps also vary hugely across cities. There is hardly any gap in London and Lyon. In contrast, there are large and significant protest differentials between migrants and natives in Madrid, Milan and Geneva. Concerning gaps involving second generations, only in Zurich gaps are negative and significant, as well as slightly more marked than gaps involving migrants.

\section{TABLE 1 ABOUT HERE}

\section{Independent variables}

Migrant-status. To assess the aforementioned gaps we consider the variable related to the migrant status of individuals, with different categories assigned based on whether individuals are natives (the reference category), migrants or second generations.

Differential individual characteristics. To test the effect of a differential access to SES resources (HY1) we look at the impact of the occupational status, and of the level of education attained. Differential levels of migration-related characteristics (HY2) are assessed by considering: the proportion of years lived in the host country (and the squared term), the legal status in the host country, the proficiency in the host country language, being Muslim, and the ethnic discrimination experienced. ${ }^{8}$ To test the effect of differential social and political attitudes (HY3) we consider political interest and social trust.

Differential effects. To test if the effect of the SES resources and social and political attitudes changes for natives, for migrants and for second generations (HY4), we include interactions between these characteristics and the migrant status.

Differential contexts. The impact of the political context on protest gaps (hypothesis 5 ) is tested using a variable measuring the openness/closure of the citizenship regime (Cinalli et al. 2014). This is a variable varying from -1 to +1 , whereby +1 refers to open citizenship regime, -1 to closed citizenship regime, and mixed situations are given a score of 0 . This variable varies at the ethnic group level as migrants from different ethnic groups may have different access to citizenship, even if living in the same city. This occurs, for instance, for Latin Americans in Spain and for ethnic Hungarians in Budapest. In both cases, these groups have an easier access to naturalization compared to other migrant groups in the respective cities of settlement. Socio-demographic characteristics such as gender, age, and being married as well as the city of residence are used as control variables. ${ }^{9}$

Table A2 in the online methodological appendix shows the descriptive statistics of the variables used by migrant status.

\section{Model specification}

We estimate random intercept logit regression models which take into account the multi-stage research design, and the correlation of data within city-groups. While the research design has a 3-level structure (with individuals at level 1, nested within 
ethnic groups at level 2, and within cities at level 3), contextual information at the ethnic group level and at the city level often overlap. Consequently, we use 2-levels models, level-2 being the ethnic group level.

We first model a nested sequence of regression models as follows (see the full models in Table A3 and A4 in the online methodological appendix): Model 0 tests the effect of the migrant status. Model 1 adds the control variables; model 2 includes the effect of differential SES resources (HY1), model 3 adds the effect of migrationrelated variables (HY2); model 4 adds the effect of social and political attitudes (HY3); model 5 tests the differential effects of individual-level covariates for natives and for individuals of migrant origin by adding the significant interactions (HY4).

Finally, model 6 tests the effect of differential contexts (HY5). This last hypothesis is only tested on the pooled sample of data in the 9 cities, given the low number of groups and cities and, therefore, of contextual characteristics, in the analyses assessing second generation-native gaps.

To facilitate the interpretability and comparability across models, the results in Tables 2 and 3 present the average marginal effects (AMEs) calculated after the estimation of the models in Table A3 and A4 (Mood, 2010). Table 2 shows the results on factors affecting migrant-native protest gaps using the pooled sample of migrants and natives in the 9 cities. In turn, table 3 shows the results on second generation-native gaps elaborated on the sample of natives and second generations in the 5 cities with a substantial presence of second generations.

As AMEs are population-averaged, they can obscure differences in effects across cases (Mood, 2010: page 78; Williams, 2012). Therefore, for the significant covariates, we also calculate marginal effects at representative values (see Table 4). In particular, we calculate the predicted probabilities and the corresponding change when a covariate shifts from its minimum to its maximum value for an individual with the following fixed characteristics: a man who is in paid work, married, interested in politics, not Muslim, holding the citizenship of the host country, living in Barcelona for the analyses concerning migrant-native gaps (in Geneva for the analyses on second generations-natives gaps), with an average score regarding continuous variables such as age, the proportion of years lived in the host country, and educational level. ${ }^{10}$

To test the robustness of our results, we also elaborate analyses on split samples of single cities (table A5 and A6 in the online methodological appendix). These analyses test differences between natives and individuals of specific ethnic groups within each city. Furthermore, as the population parameters may not be equivalent across contexts, these analyses enable us to provide some guide for understanding whether individual-level variables work differently depending on the city where individuals settled. In fact, due to the limited number of level-2 cases, we cannot include cross-level interactions between contextual and individual-level variables.

\section{Findings}

To examine migrant-native protest gaps, we consider the migrant status variable in Table 2 . Looking at model 0 , for migrants the predicted probability of demonstrating is, in average, around 5 percentage points lower than the predicted probability for natives. Single cities analyses in Tables A5 and A6 show that the AMEs of the migrant status variable in the null models are significant in most cities and for most ethnic groups. ${ }^{11}$ However, all other conditions being equal, AMEs are not significant 
(cf. model $3 \mathrm{ff}$ in Table 2 and, for most groups and cities, the full adjusted models in Tables A5 and A6). Table A5 and A6 also show that the predicted probability of protesting for migrants of some ethnic groups, namely, Turks and Chileans in Stockholm and Ethnic Hungarian in Budapest, are significantly higher than the predicted probability of protesting for natives.

\section{TABLE 2 ABOUT HERE}

In turn, considering the subsample of natives and second generations in the cities of longest immigration, namely Geneva, London, Lyon, Stockholm, and Zurich, the predicted probability of protesting for second generations are not significantly different from the predicted probability of protesting for natives (model $0 \mathrm{ff}$ in Table 3). Single city analyses in table A6 confirm this result, with the exclusion of Zurich. In addition, findings on second generations confirm previous patterns found in Stockholm. Indeed, Table A6 shows that the predicted probabilities of protesting for second generation Chileans in Stockholm are significantly higher than those for natives suggesting that Stockholm provides more opportunities of political incorporation for both migrants and second generations than other European cities.

\section{TABLE 3 ABOUT HERE}

We now turn to examine the specific factors significantly associated with the observed protest gaps. We first consider hypothesis 1 on the role of a differential access to SES resources for natives and for individuals of migrant origin. Looking at Model 2 in Table 2, the predicted probability of demonstrating is, in average, 10.9 percentage points higher for individuals having attained a high level of education than for individuals with low levels of education. This effect remains high and significant, all other conditions being equal. Looking at Table 4 showing the predicted probabilities for migrants and for natives with fixed characteristics, education has one of the strongest effects on protest engagement. In particular, when education shifts from the minimum value, not having completed primary education, to the maximum value, having a tertiary education, the predicted probability to join protests increases by around 19 percentage points for both migrants and natives. Similar results are found when examining gaps between second generations and natives (cf Table 3 for the AMEs and Table 4 for the marginal effects at representative values). We consider these results together with the average level of education attained by migrants, second generations and natives in European cities (cf. descriptive statistics in Table A2 of the online methodological appendix). In most cities, educational levels of migrants and second generations are by far lower than those of natives. Therefore, these findings suggest that a differential access to education significantly affects both migrant-native and second generation-native protest gaps, and confirm hypothesis 1 .

The occupational status affects protest gaps too (Model 2 in Table 2). In particular, there is a differential effect of the occupational status for natives and for migrants. Looking at the descriptive statistics in Table A2 there is, however, no differential access to paid work for natives and for migrants. Therefore, hypothesis 1 is not confirmed for the occupational status given that gaps are not associated with a differential access to paid work but only to a differential effect (see discussion below concerning hypothesis 4). 


\section{TABLE 4 ABOUT HERE}

We now turn to hypothesis 2 and look at the effect of the characteristics related to the migration process. Model 3 in Table 2 shows that the AMEs are positive and significant for the legal status hold by individuals, the proficiency in the host language, and the experienced discrimination. In average, holding the citizenship of the country of residence and experienced discrimination provide the greatest increase in the predicted probability to protest. Holding citizenship of the host country can indeed improve a sense of political efficacy stemming from the development of shared feelings of being part of the same political community. Similar mechanisms may also work for the proportion of years lived in the host country (see Figure 1). The effect of these characteristics remains significant all other conditions being equal (model 5 in Table 2), and confirms prior studies (cf. Tam Cho, 1999; Leal, 2002; de Rooji, 2012: page 465). Considering the shift from the minimum to the maximum values of the migrant-related variables for individuals with fixed characteristics, Table 4 shows that the predicted probability of joining protests for migrants with high level of assimilation (who hold the citizenship of the host country, who have lived for a high number of years in the host country, and have a good proficiency in the language of the host country) increases between around 8 and 11 percentage points. Furthermore, Figure 1 shows the curvilinear relationship between the proportion of years lived in the host country and protests. Up to a certain threshold, the higher the proportion of years lived in the host country, the higher the likelihood to protest. Natives and migrants who have lived 70 percent of their life in the host country have the highest probability to protest. After this threshold, however, the relationship turns negative.

\section{FIGURE 1 ABOUT HERE}

To fully acknowledge the effect of the migration-related variables on protest gaps we consider the distribution of these variables among migrants and natives (see Table A2). Assimilation of migrants is especially weak in the cities of Milan and Zurich considering, in particular, the percentage of migrants holding the citizenship of the host country. Zurich also shows the lowest percentage of migrants who speak the host country language fluently. Therefore, weak processes of assimilation, especially in these cities, are associated with increasing protest gaps, and confirm hypothesis 2 as far as migrants-natives gaps are concerned. Findings on the impact of experienced discrimination suggest a form of reactive participation (Rim, 2009). Given that migrants are likely to react to their conditions by protesting, and the fact that they experience more discrimination than natives (see Table A2), gaps are likely to decrease, further confirming hypothesis 2 on the expected effect of experienced discrimination. Considering the latter, while Stockholm stands out as the city providing more opportunities for migrants to protest, the high level of experienced discrimination by migrants in Stockholm also show that some migrants participate because they have suffered discrimination due to their ethnic origin. In turn, being Muslim is not significant for joining protests, against hypothesis 2, suggesting that Muslims are not less politically engaged than other individuals (see also Sanders et al 2014).

Considering second generation-native gaps, both holding citizenship and experienced discrimination increase, in average, the predicted probability of second generations to join protests (model 3 and 4 in Table 3 ). Looking at Table 4 the predicted 
probability for migrants with fixed characteristics increase by 13 percentage points when migrants shift from holding a permit to stay to holding the citizenship of the host country (Table 4) and of 10 percentage points when they experience discrimination (Table 4). Other migration-related characteristics are, however, not significant. Therefore, hypothesis 2 is only partly confirmed for second generationnative gaps.

We now turn to assess the impact of social and political attitudes for migrant-native gaps (Model 4 in Table 2) and test hypothesis 3. As expected, the AMEs regarding social and political attitudes are significant and the predicted probability for individuals who are interested in political issues, and for individuals who have high levels of social trust, are significantly higher than the predicted probability of protesting for individuals with weak political interests and low levels of trust. The effect remains significant in the full adjusted model (model 5 in Table 2). Looking at Table 4 showing the marginal effects for individuals with fixed characteristics, political interest and trust are associated with an increase of respectively around 14 and 11 percentage points for both natives and migrants. As it was for SES resources, levels of trust and political interest are lower for migrants and for second generations than they are for natives across most cities (Table A2). Therefore, hypothesis 3 advancing that gaps are affected by differential levels of interest and of trust is confirmed for migrant-native gaps.

Trust is, in contrast, not significant in affecting second generation-native gaps (see Table 3). In turn, political interest is significant and has a differential effect for natives and second generations as discussed below with regard to hypothesis 4 .

Turning to hypothesis 4, we consider differential effects of SES resources and social and political attitudes for natives and for individuals of migrant origin. Considering migrant-native gaps, Figure 2 shows the differential effect of the occupational status for migrants and for natives.

\section{FIGURE 2 ABOUT HERE}

Being in paid work is a useful resource for natives, but it is less so for migrants. Figure 2 shows that for natives, the average predicted probability to join demonstrations when individuals shift from any occupational status to paid work always increases, with the exclusion of the shift from students to paid work. ${ }^{12} \mathrm{In}$ contrast, the average predicted probability of migrants only increases when their occupational status shifts from doing housework and, less, from unemployment to paid work. For other occupational statuses, the average predicted probability decreases. Table 4 also shows that, for individuals with fixed characteristics, the widest differential effect on protest concerns individuals shifting from being retired and students to paid work. In particular, the predicted probability for natives who shift from retirement to paid work increases of 8.1 percentage points and, in contrast, for migrants it decreases of 7.8 percentage points. In turn, when the occupational status shifts from being a student to being in paid work, the predicted probability decreases of 1.8 percentage points for natives and of 12.5 percentage points for migrants (Table 4). The only case when paid work becomes a resource for migrants, as it is for natives, concerns individuals shifting from doing housework to paid work. This change concerns both migrants and natives and is likely to affect more women than men. ${ }^{13}$ 
Considering second generation-native gaps, the only differential effect concerns political interest. Figure 3 shows that the change in the predicted probability provided by political interest is much higher for natives than it is for second generations. Specifically, Table 4 shows that, for individuals with the same fixed characteristics, political interest increases the predicted probability to join protests by 15.4 percentage points for natives, and by barely 6 percentage points for second generations.

\section{FIGURE 3 ABOUT HERE}

Overall, we find partial evidence to confirm hypothesis 4 as we only find a differential effect of paid work for migrant-native gaps and a differential effect of political interest for second generations-native gaps. Both of the aforementioned differential effects increase the protest gap between natives and individuals of migrant origin.

Finally, we turn to our last hypothesis regarding the impact of contextual effects on protest gaps. We test this hypothesis on the sample of migrants and natives in the 9 cities (model 5 in table 2). Because of the low number of level-2 cases, the estimates of the group-level variables are more uncertain than for individual variables. Therefore, we interpret the results with great caution. Model 5 in Table 2 shows that the predicted probability of protesting for migrants living in open citizenship regimes are higher than the predicted probabilities of joining protests for migrants living in closed citizenship regimes. ${ }^{14}$ Figure 4 clearly illustrates this pattern by showing how the predicted probability to protest increases as citizenship regimes become more open.

\section{FIGURE 4 ABOUT HERE}

As table 4 shows, for individuals with fixed characteristics the change in the predicted probability to protest is over 20 percentage points when migrants shift from a closed citizenship regime to an open one. Therefore, concomitantly with education, the characteristics of the citizenship regime of the country where migrants settle is the factor which increases the predicted probability to protest the most when shifting from the minimum to the maximum value. This result confirms hypothesis 5 and is consistent with prior findings showing that migrants living in closed political contexts have significantly lower probabilities to engage in claim-makings than migrants living in more open context (Koopmans et al 2005; Cinalli and Giugni, 2011). ${ }^{15}$

\section{Conclusions}

Our study aimed to examine protest gaps between individuals of migrant origin and natives in 9 European cities. The widest protest gaps are found in the Swiss cities, Madrid, and Milan. In contrast, Stockholm stands out as the city providing more opportunities for migrants and their children to protest. Furthermore, protest gaps affecting second generations appear to be different from gaps affecting migrants, therefore confirming the relevance of studying second generations separately (Portes and Zhou, 1993).

We examined the variations in protest gaps observed in the 9 European cities by 
considering different sources of inequalities: a differential access to SES resources, differential characteristics related to migration, differential attitudes; differential effects of the aforementioned factors for natives and for individuals of migrant origin; and differential contexts offering varying opportunities of participation (Desposato and Norrander, 2008: page 146). Following our results, the strongest individual predictors of protest gaps across European cities are, in average, the level of education attained by individuals and their level of political interest. If we consider education, there are considerable educational asymmetries in most European cities whereby levels of education attained are lower for migrants and second generations than for natives. Therefore, policy programs aimed at improving educational opportunities of individuals of migrant origin are crucial. This is especially true for cities, such as the Swiss ones, where gaps in educational levels between individuals of migrant origin and natives are the widest. More generally, programs aimed at the socio-economic integration of migrants and their descendants are likely to have significant effects on protest gaps. Indeed, next to education, paid work is another condition increasing protest gaps.

Considering the effects of political interest, enhancing positive political attitudes towards the politics of the country and city of residence among individuals of migrant origin is also likely to provide more equal opportunities of political participation for individuals, regardless of their ethnic origin.

Some migration-related characteristics affect protest gaps as well. Holding the citizenship of the host country, and experienced discrimination have, in average, the strongest effects on migrant-native gaps as well as on second generation-native gaps. In addition to the aforementioned individual characteristics, this article had a crosssectional focus and provided insights into the significant impact of the context where migrants settled. Results support the claimed importance of the citizenship regime in shaping protest gaps. As far as our analyses could examine, migrant-native gaps significantly depend on the citizenship regime characterizing the place where migrants settle, and gaps are lower where access to citizenship for foreigners is easier.

Finally, our findings support a segmented assimilation hypothesis whereby different socio-economic modes of incorporation of ethnic groups affect different trajectories of political incorporation (Portes and Zhou, 1993, Zhou, 1997; Samson, 2014). While we could not test the effect of specific characteristics of the social and economic integration of migrants' ethnic group in the observed cities, results suggest that individuals who are part of ethnic groups that are well integrated in the socioeconomic contexts of the cities of settlement are more likely to participate in protest activities. This concerns migrants and second generations in Stockholm, especially Chileans, and Ethnic Hungarians in Budapest. Both Chileans and Ethnic Hungarians are indeed among the most integrated migrant groups in their respective host cities (Bevelander, 1999; Gödri, 2004). Given that our analysis was performed on 9 cities, future research may expand the analysis in a cross-sectional perspective. It may do so by including other cities and groups to incorporate an insight on specific characteristics of ethnic groups which are likely to affect political participation. An examination of dimensions related to the characteristics of the origin countries and of prior experiences of political socialization by individuals of migrant origin may also further highlight the role of factors affecting protest gaps, which this work could not explore. 


\section{References}

Aleksynska M (2011) Civic participation of immigrants in Europe: Assimilation, origin, and destination country effects. European Journal of Political Economy. 27(3): 566-585.

Bevelander P (1999) The employment integration of immigrants in Sweden Journal of Ethnic and Migration Studies. 25( 3): 445-468.

Bleich E (2009) Muslims and the State in the Post-9/11 West: Introduction. Journal of Ethnic and Migration Studies. 35(3): 353-360.

Bloemraad I (2006) Becoming a Citizen in the United States and Canada: Structured Mobilization and Immigrant Political Incorporation. Social Forces. 85(2): 667-695.

Brady HE, Verba S and Schlozman KL (1995) Beyond Ses: A Resource Model of Political Participation. The American Political Science Review. 89(2): 271-294.

Cinalli $M$ and Giugni MG (2011) Institutional Opportunities, Discursive Opportunities, and the Political Participation of Migrants. In: Morales L and Giugni MG (eds.) Social Capital, Political Participation and Migration in Europe. Making Multicultural Democracy Work?. Basingstoke: Palgrave Macmillan, pp. 43-62.

Cinalli M, Morales L, Bozec G, Devadason R, Eggert N, Morariu M, Gonzalez A, Pilati K, Ros V, Zakarias I (2014) LOCALMULTIDEM and MDE Institutional Political Opportunity Structures Indicators (WP1) Dataset, 2006, doi:10.7910/DVN/27709, Harvard Dataverse, V2

Crul, M Schneider, J. and Frans, L (2012) The European Second Generation Compared. Does the Integration Context Matter?. Amsterdam: Amsterdam University Press.

de Rooij E (2012) Patterns of Immigrant Political Participation: Explaining Differences in Types of Political Participation between Immigrants and the Majority Population in Western Europe. European Sociological Review. 28(4): 455-481. 
Desposato S, and Norrander B (2008) The Gender Gap in Latin America: Contextual and Individual Influences on Gender and Political Participation. British Journal of Political Science. 39: 141-162.

Diehl C and Schnell R (2006) "Reactive Ethnicity" or "Assimilation"? Statements, Arguments, and First Empirical Evidence for Labor Migrants in Germany. International Migration Review. 40(4): 786-816.

Dinesen PT and Hooghe M (2010) When in Rome, Do as the Romans Do: The Acculturation of Generalized Trust among Immigrants in Western Europe. International Migration Review. 44(3): 697-727.

EVS (2016) European Values Study (2008) Integrated Dataset (EVS 2008). GESIS Data Archive, Cologne. ZA4800 Data file Version 4.0.0, doi:10.4232/1.12458

Gesthuizen M, Van der Meer T and Scheepers P (2009) Ethnic diversity and social capital in Europe: tests of Putnam's thesis in European countries. Scandinavian Political Studies. 32(2): 121-142.

Gijsberts M, Van Der Meer T and Dagevos J (2012) 'Hunkering down' in multiethnic neighbourhoods? The effects of ethnic diversity on dimensions of social cohesion. European Sociological Review. 28(4): 527-537.

Gödri I (2004) A Special Case of International Migration: Ethnic Hungarians Migrating From Transylvania to Hungary. Yearbook of Population Research in Finland. 40: 45-72.

Greene W Discrete Choice Modeling.

http://archive.nyu.edu/bitstream/2451/26036/2/7-7.pdf) retrieved November 23, 2016.

Heath AF, Fisher SD, Rosenblatt G, Sanders D and Sobolewska M (2013) The Political Integration of Ethnic Minorities in Britain. Oxford: Oxford University Press.

Heath AF, Rothon C and Kilpi E (2008) The Second Generation in Western Europe: Education, Unemployment, and Occupational Attainment. Annual Review of Sociology. 34: 211-235. 
Heckathorn DD (1997) Respondent-driven sampling: a new approach to the study of hidden populations. Social problems. New York. 44: 174-199.

Hooghe M, Reeskens T, Stolle D and Trappers A (2009) Ethnic diversity and generalized trust in Europe A cross-national multilevel study. Comparative Political Studies. 42(2): 198-223.

Just A, and Anderson CJ (2014) Opinion Climates and Immigrant Political Action: A Cross-National Study of 25 European Democracies. Comparative Political Studies 47(7): 935-965.

Koopmans R, Statham P, Giugni M and Passy F (2005) Contested citizenship: Immigration and cultural diversity in Europe. Minneapolis: University of Minnesota Press.

Kovats A, Kucaba K, Devadason R, Eggert M, Giugni MG, Gonzalez A, Hars A, Morariu M, Nasri F, Pilati K and Varadi L (2016) LOCALMULTIDEM and MDE Socio-Demographic Statistics (WP2) Dataset, 1990-2005. http://dx.doi.org/10.7910/DVN/UJYNDF, Harvard Dataverse, V1

Leal DL (2002) Political participation by Latino non-citizens in the United States. British Journal of Political Science. 32(2): 353-370.

Maxwell R (2010) "Evaluating Migrant Integration: Political Attitudes Across Generations in Europe. International Migration Review. 44(1): 25-52.

McCarthy JD and Mayer NZ (1977) Resource mobilization and social movements: A partial theory. The American Journal of Sociology 82(6): 1212-1241.

Melucci A (1996) Challenging Codes: Collective Action in the Information Age. Cambridge: Cambridge University Press.

Messina A (2007) The Logics and Politics of Post Wwii Migration to Western Europe. Cambridge: Cambridge University Press.

Mood C (2010) Logistic Regression: Why We Cannot Do What We Think We Can Do, and What We Can Do About It. European Sociological Review. 26(1): 67-82. 
Morales L (2011) Conceptualising and Measuring Migrants' Political Inclusion. In: Morales L and Giugni MG (eds) Social Capital, Political Participation and Migration in Europe. Making Multicultural Democracy Work?. Basingstoke: Palgrave Macmillan, pp. 19-42.

Morales L, Anduiza E, Bengtsson B, Cinalli M, Diani M, Örkény A, Rogstad J and Statham P (2014) LOCALMULTIDEM and MDE Individual Survey (WP4) Dataset, 2004-2008. [Online]

Available at: http://dx.doi.org/10.7910/DVN/24987 Harvard Dataverse Network [Distributor] V2 [Version]

Morales L and Pilati K (2011) The role of social capital in migrants' engagement in local politics in European cities. In: Morales L and Giugni MG (eds) Social Capital, Political Participation and Migration in Europe. Making Multicultural Democracy Work? Basingstoke: Palgrave Macmillan, pp.87-114

Palacios I and Morales L (2013) LOCALMULTIDEM and MDE Individual Surveys (WP4) Technical Report. Version 1. University of Leicester, Leicester.

Penninx R, Kraal K, Martiniello M and Vertovec S (2004) Citizenship in European Cities - Immigrants, Local Politics and Integration Policies. Ashgate: Aldershot.

Pilati K (2016) Migrants' Political Participation in Exclusionary Contexts. From subcultures to radicalization, Palgrave Pivot Series, Basingstoke: PalgraveMacmillan.

Pilati K and Morales L (2016) Ethnic and immigrant politics vs mainstream politics: the role of ethnic organizations in shaping the political participation of immigrantorigin individuals in Europe. Ethnic and Racial Studies. 39(15): 2796-2817.

Portes A and Zhou M (1993) The new second generation: segmented assimilation and its variants. The ANNALS of the American Academy of Political and Social Science. 530: 74-96.

Putnam R (2007) E Pluribus Unum: Diversity and Community in the Twentyfirst Century. The 2006 Johan Skytte Prize Lecture. Scandinavian Political Studies. 30(2): 137-74.

Ramakrishnan S and Espenshade TJ (2001) Immigrant Incorporation and Political Participation in the United States. International Migration Review 35(3): 870-907. 
Rim K (2009) Racial Context Effects and the Political Participation of Asian Americans. American Politics Research. 37(4): 569-592.

Rosenstone S and Hansen J (2003) Mobilization, Participation, and Democracy in America. New York: Longman.

Samson F (2014) Segmented political assimilation: perceptions of racialized opportunities and Latino immigrants' partisan identification. Ethnic and Racial Studies. 37(3): 467-495.

Sanders D, Fisher S, Heath A and Sobolewska M (2014) The democratic engagement of Britain's ethnic minorities. Ethnic and Racial Studies. 37(1): 120-139.

Sturgis P, Brunton-Smith I, Read S and Allum N (2011) Does ethnic diversity erode trust? Putnam's 'hunkering down' thesis reconsidered. British Journal of Political Science. 41(01): 57-82.

Tam Cho W (1999) Naturalization, Socialization, Participation: Immigrants and (Non-) Voting. The Journal of Politics. 61(4): 1140-55.

Terriquez V and Kwon H (2015) Intergenerational Family Relations, Civic Organisations, and the Political Socialisation of Second-Generation Immigrant Youth. Journal of Ethnic and Migration Studies 41: 425-447 .

Uhlaner C, Cain B and Kiewiet R (1989) Political Participation of Ethnic Minorities in the 1980s. Political Behavior. 11(3): 195-231.

Verba S and Nie NH (1972) Participation in America: Political democracy and social equality. New York : Harper and Row.

Voicu B (2014) Participative immigrants or participative cultures? The importance of cultural heritage in determining involvement in associations. VOLUNTAS: International Journal of Voluntary and Nonprofit Organizations. 25(3): 612-635.

White S, Nevitte N, Blais A, Gidengil E and Fournier P (2008) The Political Resocialization of Immigrants: Resistance or Lifelong Learning?. Political Research Quarterly. 61(2): 268-281. 
Williams R (2012) Using the margins command to estimate and interpret adjusted predictions and marginal effects. The Stata Journal. 12(2): 308-331.

Wong J, Lien P and Conway M (2005) Group-based resources and political participation among Asian Americans. American Politics Research. 33(4): 545-576.

Zhou M (1997) Segmented Assimilation: Issues, Controversies, and Recent Research on the New Second Generation. International Migration Review. 31(4): 975-1008.

\section{Author biography:}

Katia Pilati is Assistant Professor at the Department of Sociology and Social Research (DSRS) at the University of Trento, Italy (PhD University of Trento, DSRS). Her research interests include civic and political participation, immigration, social movements, social networks. Her publications appeared in European Journal of Political Science, Journal of Ethnic and Migration Studies, Global Networks, Mobilization, Ethnic and Racial Studies. She is the author of two books (Armando 2010; Palgrave Macmillan 2016).

\section{Acknowledgements}

Results presented in this paper stem from integrated datasets produced by the project "Multicultural Democracy and Immigrants' Social Capital in Europe: Participation, Organizational Networks, and Public Policies at the Local Level (LOCALMULTIDEM)". This project was funded by the European Commission under the $6^{\text {th }}$ Framework Programme's Priority 7 "Citizens and Governance in a KnowledgeBased Society" as a STREP instrument (contract no. CIT5-CT-2005-028802). The LOCALMULTIDEM consortium was coordinated by the University of Murcia (Dr. Laura Morales), and was formed by the University of Geneva (Dr. Marco Giugni), the University of Trento (Dr. Mario Diani), the University of Bristol (Dr. Paul Statham), the CEVIPOF - Sciences Po Paris (Dr. Manlio Cinalli), the MTAKI (Dr. Endre Sik), and the University of Manchester (Dr. Laura Morales).

I thank the three anonymous reviewers and Sabrina Perra for the extremely useful insights provided on the previous drafts of the article. 
${ }^{1} 1.5$ generation include individuals who migrated before or during their early teens.

${ }^{2}$ For the sake of parsimony, we refer to second generations in the text but effectively analyze both second and third generations.

${ }^{3}$ Contextual dimensions affect second generations' integration as well (see Crul et al 2012). However, due to the low number of cities and ethnic groups where the presence of second generations is substantial, we do not put forward any specific hypothesis on contextual effects concerning gaps involving second generations.

${ }^{4}$ Ethnic groups differences within single cities are examined in Tables A1, A5 and A6.

${ }^{5}$ Ethnic Hungarians are migrants from Hungarian communities across the borders of contemporary Hungary.

${ }^{6}$ With the exclusion of Stockholm, the sample of natives and the sample of second generation native peers largely overlap due to the presence of elderly people in the second generation sample. Therefore, we provide the comparison with natives.

${ }^{7}$ As it will be later shown (cf Tables A2 and Table A5), the results in Budapest are mainly driven by Ethnic Hungarians' rates of participation.

${ }^{8}$ Natives in Lyon were not asked about experiences of discrimination. Analyses on the second generation-native sample omit the proportion of years lived in the host country and the squared term due to the low number of cases who have not lived in the host country.

${ }^{9}$ Due to various reasons, inter-alia, the lack of data, we could not test the impact of some variables such as the characteristics of migrants' origin countries, previous experiences of political socialization, neighborhood-level variables, collective identities (cf. Wong et al., 2005; Aleksynska, 2011; Sturgis et al., 2011; Voicu, 
2014). For the relationship between migrants' organizational involvement and political engagement cf. Pilati and Morales (2016).

${ }^{10}$ Estimates in Table 4 have been calculated based on model 6 in table A5 for the migrant-native sample, and on model 5 in table A6 for the second generation-native sample.

${ }^{11}$ AMEs concerning the migrant status variable in Model 0 of Table 2 are not significant. However, as shown by model 0 in Table A3, the odds ratios are significant, although marginally. Following Greene (2008: page 12) we make inference about the estimated odds ratios, not the associated marginal effects.

${ }^{12}$ AMEs in Figure 2 are not significant (the confidence intervals of predicted probabilities are omitted to make the figure clearer). However, as shown by model 5 in Table A3, the odds ratios concerning the interaction between the occupational status and the migrant status are significant.

${ }^{13}$ Table A3 and Figure A1 of the online methodological appendix shows that being married has a differential effect for migrants and for natives too, widening the gap. This is not further commented given that being married is only a control variable. It nonetheless suggests that married migrants are likely to have family burdens limiting their political activities.

${ }^{14}$ The AME concerning the citizenship regime is not significant but the odds ratios are, although at a marginal level (cf. model 6 of Table A3). As specified in note 10, fFollowing Greene (2008: page 12) we make inference about the estimated odds ratios not the associated marginal effects.

${ }^{15}$ Given the limited space, we omit to discuss the findings concerning the control variables. 


\section{TABLES}

Table 1 Participatory rates (mean) by migrant status (native, migrant, second generation), and corresponding gaps by city

\begin{tabular}{lllllll}
\hline & GROUP & \multicolumn{5}{c}{ GAPS } \\
\cline { 2 - 7 } & Natives & Migrants & $\begin{array}{l}\text { Second and } \\
\text { third } \\
\text { generations }\end{array}$ & $\begin{array}{l}\text { Migrant- } \\
\text { native }\end{array}$ & $\begin{array}{l}\text { Second- } \\
\text { generation- } \\
\text { native }\end{array}$ & $\mathrm{N}$ \\
\hline Barcelona & 0.135 & 0.072 & & $-0.063^{* *}$ & & 1,002 \\
Budapest & 0.027 & 0.056 & & $0.029^{*}$ & & 1,397 \\
Geneva & 0.127 & 0.022 & 0.067 & $-0.106^{* * *}$ & -0.060 & 922 \\
London & 0.017 & 0.016 & 0.016 & -0.001 & -0.001 & 1,178 \\
Lyon & 0.265 & 0.241 & 0.251 & -0.024 & -0.015 & 1,045 \\
Madrid & 0.218 & 0.065 & & $-0.154^{* * *}$ & & 1,085 \\
Milan & 0.170 & 0.036 & & $-0.134^{* * *}$ & & 1,037 \\
Stockholm & 0.083 & 0.240 & 0.218 & $0.157^{* * *}$ & $0.135^{* * *}$ & 832 \\
Zurich & 0.088 & 0.035 & 0.030 & $-0.053^{* * *}$ & $-0.058^{+}$ & 1,181 \\
\hline$+0.1 * * * \mathrm{p} \leq 0.001 ; \mathrm{p} \leq 0.01:{ }^{*} \mathrm{p} \leq 0.05$ & & & &
\end{tabular}


Table 2 Predictors of engagement in demonstrations, native and migrant sample (random intercept logit models; average marginal effects and standard errors of marginal effects in parenthesis).

\begin{tabular}{|c|c|c|c|c|c|c|c|c|c|c|c|c|}
\hline & Model 0 & & Model 1 & & Model 2 & & Model 3 & & Model 4 & & Model 5 & \\
\hline & AME & se & AME & se & AME & se & AME & se & AME & se & AME & se \\
\hline \multicolumn{13}{|l|}{ Migrant status: Native (Ref.) } \\
\hline Migrant & -0.050 & $(0.036)$ & $-0.065^{*}$ & $(0.025)$ & $-0.050^{*}$ & $(0.023)$ & -0.013 & $(0.020)$ & -0.007 & $(0.020)$ & 0.032 & $(0.03:$ \\
\hline \multicolumn{13}{|l|}{ Control variables } \\
\hline Male & & & $0.012^{*}$ & $(0.006)$ & 0.007 & $(0.006)$ & 0.008 & $(0.006)$ & 0.004 & $(0.006)$ & 0.005 & $(0.00$ \\
\hline Age & & & $-0.000^{*}$ & $(0.000)$ & 0.000 & $(0.000)$ & 0.000 & $(0.000)$ & -0.000 & $(0.000)$ & -0.000 & $(0.00$ \\
\hline Married & & & $-0.023^{* * *}$ & $(0.007)$ & $-0.018^{* *}$ & $(0.007)$ & $-0.017^{* *}$ & $(0.007)$ & $-0.018^{*}$ & $(0.007)$ & $-0.018^{*}$ & $\left(0.00^{\prime}\right.$ \\
\hline \multicolumn{13}{|l|}{ City of residence: Barcelona (ref) } \\
\hline Budapest & & & $-0.064^{*}$ & $(0.031)$ & $-0.072^{*}$ & $(0.030)$ & $-0.073^{* *}$ & $(0.026)$ & $-0.081^{* *}$ & $(0.026)$ & $-0.062^{*}$ & $(0.02$ \\
\hline Geneva & & & -0.042 & $(0.035)$ & -0.049 & $(0.034)$ & $-0.054^{+}$ & $(0.029)$ & $-0.061^{*}$ & $(0.029)$ & -0.035 & $(0.03$ : \\
\hline London & & & $-0.078^{* *}$ & $(0.030)$ & $-0.084^{* *}$ & $(0.030)$ & $-0.093^{* * *}$ & $(0.025)$ & $-0.097^{* * *}$ & $(0.026)$ & $-0.085^{* * *}$ & $(0.02$. \\
\hline Lyon & & & $0.160^{*}$ & $(0.070)$ & $0.153^{*}$ & $(0.066)$ & $0.093^{*}$ & $(0.046)$ & $0.077^{+}$ & $(0.045)$ & $0.115^{*}$ & $(0.05$ : \\
\hline Madrid & & & 0.003 & $(0.041)$ & 0.015 & $(0.043)$ & 0.019 & $(0.036)$ & 0.020 & $(0.037)$ & 0.015 & $(0.03$ : \\
\hline Milan & & & -0.029 & $(0.036)$ & -0.031 & $(0.036)$ & -0.015 & $(0.033)$ & -0.013 & $(0.035)$ & 0.006 & $(0.03$ ، \\
\hline Stockholm & & & 0.080 & $(0.062)$ & 0.066 & $(0.057)$ & 0.017 & $(0.038)$ & 0.008 & $(0.038)$ & 0.001 & $(0.03:$ \\
\hline Zurich & & & -0.040 & $(0.034)$ & -0.038 & $(0.035)$ & -0.033 & $(0.031)$ & -0.039 & $(0.031)$ & 0.001 & $(0.04$ \\
\hline \multicolumn{13}{|l|}{ Differential resources (HY1) } \\
\hline \multicolumn{13}{|l|}{ Occupation: in paid work (REF) } \\
\hline in education & & & & & $0.027^{+}$ & $(0.014)$ & $0.031^{*}$ & $(0.015)$ & $0.033^{*}$ & $(0.015)$ & $0.030^{*}$ & $(0.01$ : \\
\hline unemployed & & & & & -0.014 & $(0.011)$ & -0.012 & $(0.011)$ & -0.009 & $(0.012)$ & -0.008 & $(0.01$ : \\
\hline retired & & & & & $-0.024^{+}$ & $(0.013)$ & -0.018 & $(0.014)$ & -0.018 & $(0.014)$ & -0.001 & $(0.021$ \\
\hline doing housework & & & & & $-0.049^{* * *}$ & $(0.012)$ & $-0.049^{* * *}$ & $(0.012)$ & $-0.047^{* * *}$ & $(0.013)$ & $-0.048^{* * *}$ & $(0.01$ : \\
\hline other & & & & & -0.019 & $(0.014)$ & -0.009 & $(0.016)$ & -0.005 & $(0.017)$ & -0.013 & $\left(0.01^{\prime}\right.$ \\
\hline Highest level of education attained & & & & & $0.109^{* * *}$ & $(0.014)$ & $0.107^{* * *}$ & $(0.013)$ & $0.081^{* * *}$ & $(0.013)$ & $0.081^{* * *}$ & $(0.01$ \\
\hline \multicolumn{13}{|c|}{ Differential immigration-related characteristics (HY2) } \\
\hline Muslim & & & & & & & -0.007 & $(0.011)$ & -0.006 & $(0.012)$ & 0.000 & $(0.01:$ \\
\hline Proportion of years lived in the host country & & & & & & & -0.014 & $(0.024)$ & -0.012 & $(0.025)$ & -0.013 & $(0.02$ : \\
\hline Legal situation: (no citizenship nor permit) & & & & & & & -0.002 & $(0.016)$ & -0.005 & $(0.017)$ & -0.007 & $\left(0.01^{\prime}\right.$ \\
\hline Holds citizenship of the residence country & & & & & & & $0.041^{* * *}$ & $(0.010)$ & $0.042^{* * *}$ & $(0.010)$ & $0.041^{* * *}$ & $(0.011$ \\
\hline \multicolumn{13}{|l|}{ Has permit to stay (Ref.) } \\
\hline Language proficiency & & & & & & & $0.040^{* * *}$ & $(0.010)$ & $0.037^{* * *}$ & $(0.011)$ & $0.037^{* * *}$ & $(0.01$ \\
\hline Has experienced discrimination & & & & & & & $0.039^{* * *}$ & $(0.011)$ & $0.040^{* * *}$ & $(0.011)$ & $0.041^{* * *}$ & $(0.01$ : \\
\hline \multicolumn{13}{|l|}{ Social and political attitudes (HY3) } \\
\hline Interested in the host country politics & & & & & & & & & $0.068^{* * *}$ & $(0.008)$ & $0.068^{* * *}$ & $(0.00$ \\
\hline Trust & & & & & & & & & $0.046^{* * *}$ & $(0.013)$ & $0.047^{* * *}$ & $(0.01$ : \\
\hline \multicolumn{13}{|l|}{ Differential contexts (HY5) } \\
\hline POS citizenship regime & & & & & & & & & & & 0.049 & $(0.03 !$ \\
\hline $\mathrm{Ll}$ & -2326.36 & & -2263.42 & & -2177.52 & & -2081.14 & & -1983.60 & & -1971.93 & \\
\hline $\mathrm{N}$ & 8,640 & & 8,485 & & 8,378 & & 8,021 & & 7,655 & & 7,655 & \\
\hline
\end{tabular}

NOTE: AMEs have been calculated after the models reported in TABLE A3 in the online methodological appendix

Significance levels: $+0.1{ }^{*} \mathrm{p}<.05{ }^{* *} \mathrm{p}<.01{ }^{* * *} \mathrm{p}<.001$ 
Table 3 Predictors of engagement in demonstrations, native and second generation sample (random intercept logit models; average marginal effects and standard errors of marginal effects in parenthesis).

\begin{tabular}{|c|c|c|c|c|c|c|c|c|c|c|}
\hline & & \multirow{2}{*}{$\begin{array}{l}\text { Model } 1 \\
\text { AME }\end{array}$} & \multicolumn{3}{|c|}{ Model 2} & \multirow{2}{*}{$\begin{array}{c}\text { Model } 3 \\
\text { AME }\end{array}$} & \multicolumn{3}{|c|}{ Model 4} \\
\hline & AME & se & & se & AME & se & & se & AME & se \\
\hline \multicolumn{11}{|l|}{ Migrant status: Native (Ref.) } \\
\hline Migrant & -0.025 & $(0.059)$ & -0.024 & $(0.032)$ & -0.007 & $(0.032)$ & 0.001 & $(0.033)$ & 0.006 & $(0.035)$ \\
\hline \multicolumn{11}{|l|}{ Control variables } \\
\hline Male & & & 0.001 & $(0.013)$ & 0.001 & $(0.013)$ & 0.000 & $(0.013)$ & -0.003 & $(0.013)$ \\
\hline Age & & & -0.001 & $(0.001)$ & -0.000 & $(0.001)$ & -0.000 & $(0.001)$ & -0.000 & $(0.001)$ \\
\hline Married & & & 0.000 & $(0.014)$ & 0.002 & $(0.014)$ & 0.002 & $(0.014)$ & 0.000 & $(0.014)$ \\
\hline \multicolumn{11}{|l|}{ City of residence: Geneva (ref) } \\
\hline London & & & $-0.085^{*}$ & $(0.036)$ & $-0.079^{*}$ & $(0.033)$ & $-0.103^{* *}$ & $(0.036)$ & $-0.101^{* *}$ & $(0.038)$ \\
\hline Lyon & & & $0.167^{*}$ & $(0.066)$ & $0.182^{* *}$ & $(0.064)$ & $0.133^{*}$ & $(0.058)$ & $0.128^{*}$ & $(0.062)$ \\
\hline Stockholm & & & 0.054 & $(0.059)$ & 0.060 & $(0.057)$ & 0.026 & $(0.054)$ & 0.024 & $(0.056)$ \\
\hline Zurich & & & -0.043 & $(0.041)$ & -0.034 & $(0.039)$ & -0.033 & $(0.043)$ & -0.039 & $(0.045)$ \\
\hline \multicolumn{11}{|l|}{ Differential resources (HY1) } \\
\hline \multicolumn{11}{|l|}{ Occupation: in paid work (REF) } \\
\hline in education & & & & & 0.005 & $(0.025)$ & 0.011 & $(0.026)$ & 0.006 & $(0.026)$ \\
\hline unemployed & & & & & -0.030 & $(0.022)$ & -0.030 & $(0.022)$ & -0.029 & $(0.022)$ \\
\hline retired & & & & & -0.045 & $(0.031)$ & -0.045 & $(0.030)$ & -0.046 & $(0.030)$ \\
\hline doing housework & & & & & -0.050 & $(0.031)$ & -0.048 & $(0.030)$ & -0.048 & $(0.031)$ \\
\hline other & & & & & $-0.058^{+}$ & $(0.031)$ & $-0.053^{+}$ & $(0.032)$ & -0.046 & $(0.035)$ \\
\hline Highest level of education attained & & & & & $0.119^{* * *}$ & $(0.028)$ & $0.113^{* * *}$ & $(0.027)$ & $0.089^{* *}$ & $(0.027)$ \\
\hline \multicolumn{11}{|c|}{ Differential immigration-related characteristics (HY2) } \\
\hline Muslim & & & & & & & -0.002 & $(0.026)$ & 0.003 & $(0.027)$ \\
\hline Legal situation: (no citizenship nor permit) & & & & & & & -0.017 & $(0.039)$ & -0.023 & $(0.041)$ \\
\hline Holds citizenship of the residence country & & & & & & & $0.079^{* *}$ & $(0.028)$ & $0.072^{*}$ & $(0.032)$ \\
\hline \multicolumn{11}{|l|}{ Has permit to stay (Ref.) } \\
\hline Language proficiency & & & & & & & 0.009 & $(0.051)$ & 0.004 & $(0.053)$ \\
\hline Has experienced discrimination & & & & & & & $0.077^{* *}$ & $(0.028)$ & $0.080^{* *}$ & $(0.029)$ \\
\hline \multicolumn{11}{|l|}{ Social and political attitudes (HY3) } \\
\hline Interested in the host country politics & & & & & & & & & $0.066^{* * *}$ & $(0.015)$ \\
\hline Trust & & & & & & & & & 0.040 & $(0.026)$ \\
\hline L1 & -823.72 & & -800.61 & & -782.65 & & -762.13 & & -746.47 & \\
\hline $\mathrm{N}$ & 2,566 & & 2,488 & & 2,435 & & 2,387 & & 2,357 & \\
\hline
\end{tabular}

NOTE: AMEs have been calculated after the models reported in TABLE A4 in the online methodological appendix

Significance levels: $+0.1{ }^{*} \mathrm{p}<.05{ }^{* *} \mathrm{p}<.01{ }^{* * *} \mathrm{p}<.001$ 
Table 4 Predicted probabilities and marginal effects of protesting for natives and for migrants with fixed characteristics (left side); and for natives and second generations with fixed characteristics (rights side)

\begin{tabular}{|c|c|c|c|c|c|c|c|c|c|c|c|c|}
\hline \multirow{4}{*}{$\begin{array}{l}\text { Education } \\
\text { Occupation (from "in education" to "in paid work") } \\
\text { Occupation (from "retired" to "in paid work") }\end{array}$} & \multicolumn{2}{|c|}{ MIN VALUE } & \multicolumn{2}{|c|}{$\begin{array}{c}\text { MAX } \\
\text { VALUE }\end{array}$} & \multicolumn{2}{|c|}{ CHANGE } & \multicolumn{2}{|c|}{$\begin{array}{c}\text { MIN } \\
\text { VALUE }\end{array}$} & \multicolumn{2}{|c|}{$\begin{array}{c}\text { MAX } \\
\text { VALUE }\end{array}$} & \multicolumn{2}{|c|}{ CHANGE } \\
\hline & $\begin{array}{l}\text { Nat. } \\
0.134\end{array}$ & $\begin{array}{l}\text { Mig. } \\
0.138\end{array}$ & $\begin{array}{l}\text { Nat. } \\
0.322\end{array}$ & $\begin{array}{l}\text { Mig. } \\
0.330\end{array}$ & $\begin{array}{l}\text { Nat. } \\
0.188\end{array}$ & $\begin{array}{l}\text { Mig. } \\
0.192\end{array}$ & $\begin{array}{l}\text { Nat. } \\
0.142\end{array}$ & $\begin{array}{l}\text { Sec. } \\
0.131\end{array}$ & $\begin{array}{l}\text { Nat. } \\
0.291\end{array}$ & $\begin{array}{l}\text { Sec. } \\
0.272\end{array}$ & $\begin{array}{l}\text { Nat. } \\
0.149\end{array}$ & $\begin{array}{l}\text { Sec. } \\
0.141\end{array}$ \\
\hline & 0.256 & 0.369 & 0.238 & 0.244 & -0.018 & -0.125 & & & & & & \\
\hline & 0.157 & 0.322 & 0.238 & 0.244 & 0.081 & -0.078 & & & & & & \\
\hline Occupation (from "doing housework" to "in paid work") & 0.107 & 0.133 & 0.238 & 0.244 & 0.131 & 0.111 & & & & & & \\
\hline Occupation (from "other" to "in paid work") & 0.134 & 0.29 & 0.238 & 0.244 & 0.104 & -0.046 & & & & & & \\
\hline Legal status a & & 0.152 & & 0.244 & & 0.092 & & 0.095 & & 0.225 & & 0.130 \\
\hline Discrimination experienced & 0.158 & 0.162 & 0.238 & 0.244 & 0.080 & 0.082 & 0.135 & 0.125 & 0.241 & 0.225 & 0.106 & 0.100 \\
\hline Language proficiency & 0.149 & 0.153 & 0.238 & 0.244 & 0.089 & 0.091 & & & & & & \\
\hline Proportion of years lived in the host country ${ }^{b}$ & 0.127 & 0.131 & 0.238 & 0.244 & 0.111 & 0.113 & & & & & & \\
\hline Trust & 0.184 & 0.189 & 0.300 & 0.307 & 0.116 & 0.118 & & & & & & \\
\hline Interest & 0.096 & 0.099 & 0.238 & 0.244 & 0.142 & 0.145 & 0.087 & 0.166 & 0.241 & 0.225 & 0.154 & 0.059 \\
\hline POS citizenship regime ${ }^{c}$ & & 0.107 & & 0.315 & & 0.208 & & & & & & \\
\hline
\end{tabular}

NOTES: Nat.=natives; Mig.=migrants; Sec. $=$ Second/third generation; estimated based on model 6 in table A5; only significant predictors shown; control variables not shown. Min value for both dichotomous and continuous variables $=0 ;$ max value $=1$.

a. Min value "legal status"= has permit to stay; Max value=Holds citizenship; only calculated on migrants given that for natives this value is equal to 1

b. Min value "Proportion of years lived in the host country" $=0$; Max Value $=0.7$;

c. POS citizenship regime (Min value $=-1$ to Max value $=1$ 


\section{FIGURES}

FIGURE 1 The effect of the proportion of years lived in the host country

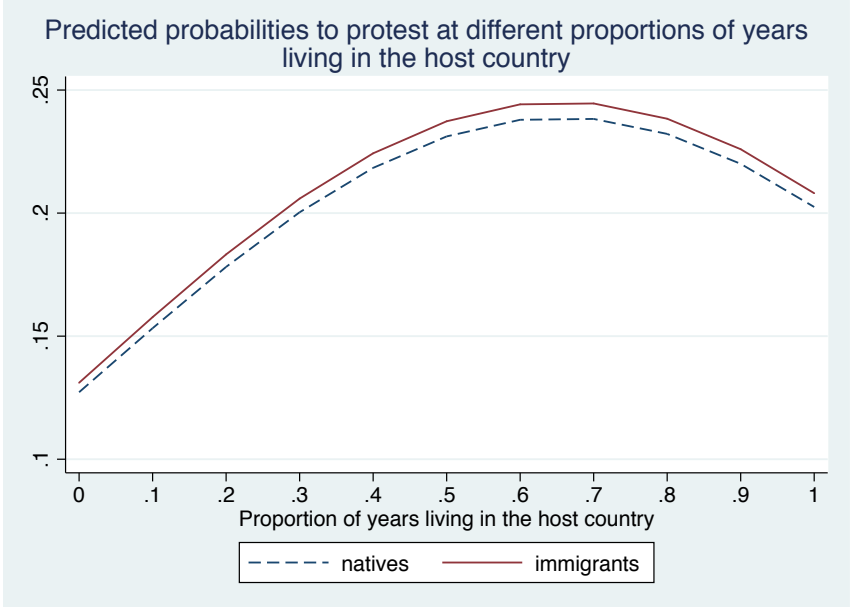

FIGURE 2 Differential effect of occupational status for migrants and for natives

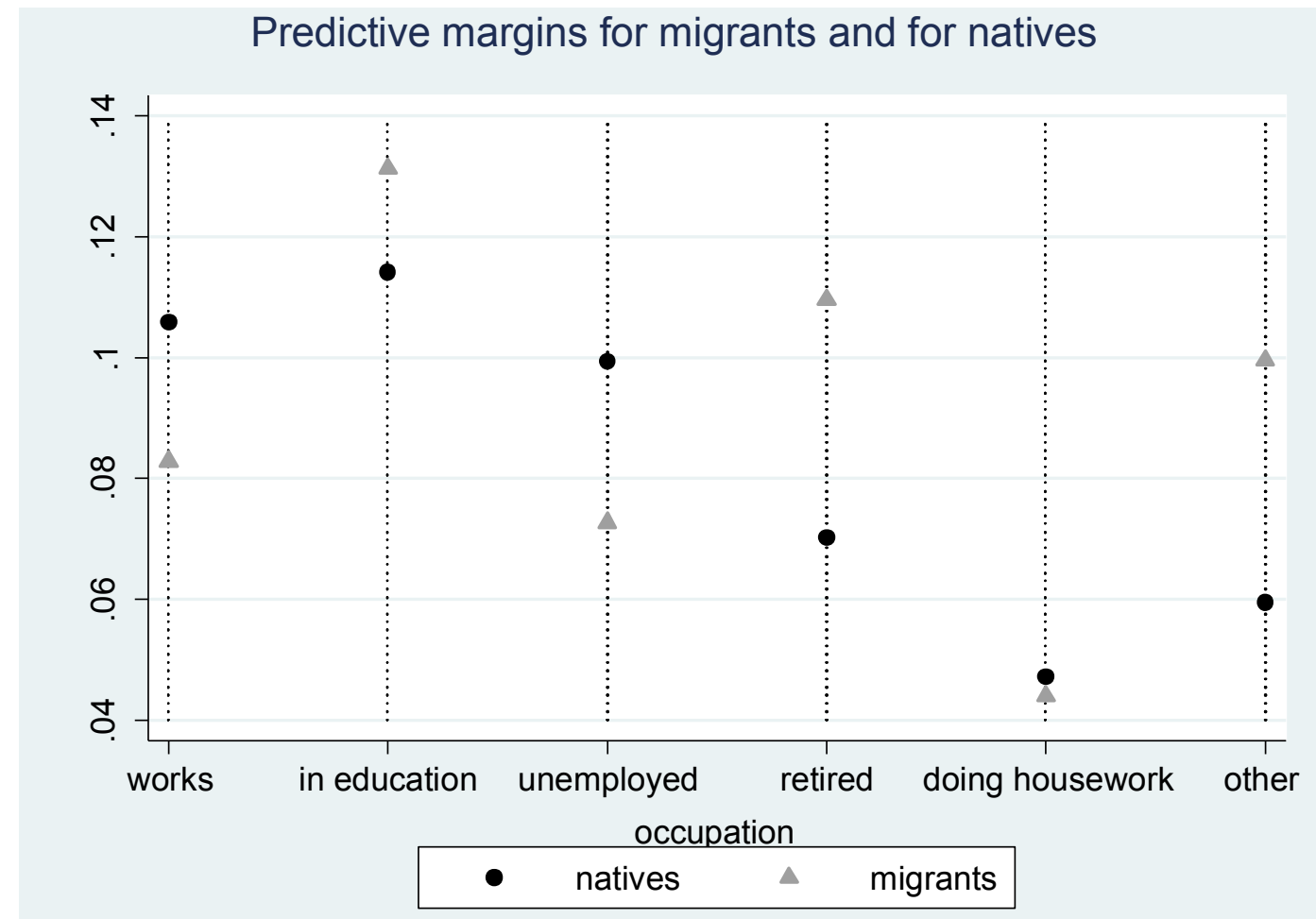


FIGURE 3 Differential effect of political interests for second generations and for natives

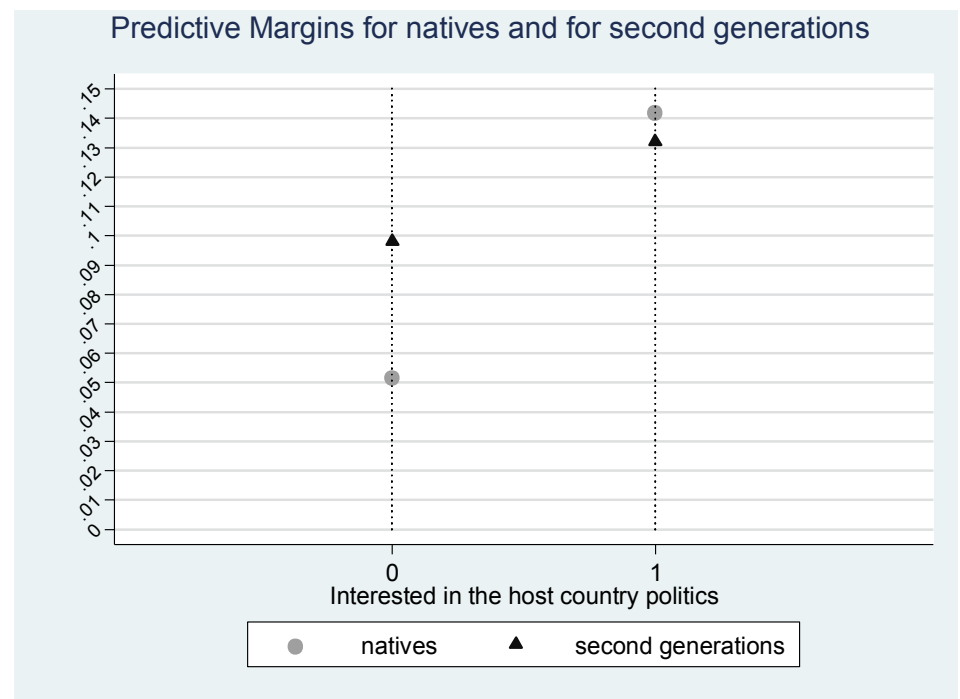

Figure 4 Contextual effect of citizenship regime

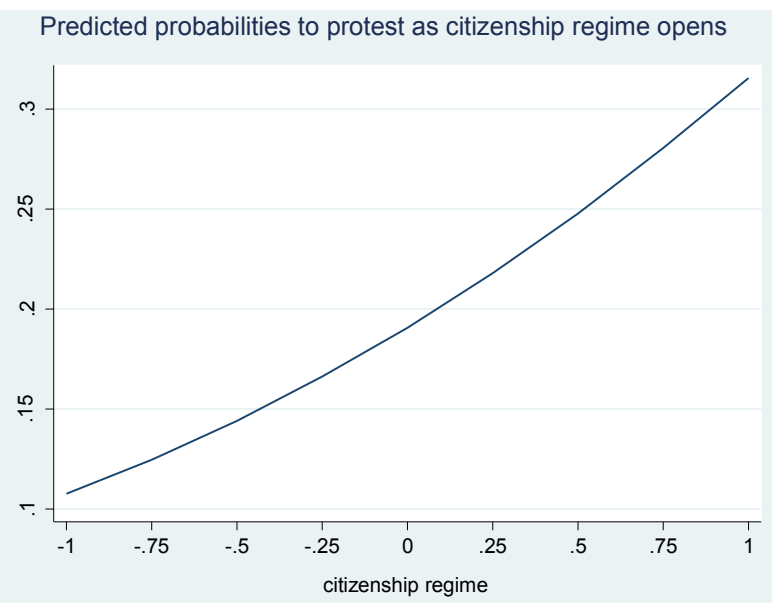

